\begin{tabular}{|c|c|}
\hline \multirow{3}{*}{ 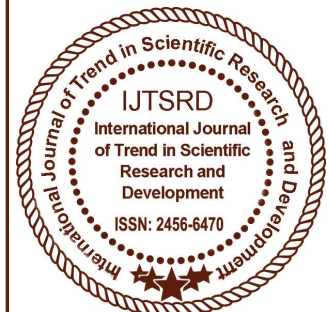 } & $\begin{array}{l}\text { International Journal of Trend in Scientific } \\
\text { Research and Development (IJTSRD) }\end{array}$ \\
\hline & International Open Access Journal \\
\hline & ISSN No: 2456 - 6470 | www.ijtsrd.com | Volume - 2 | Issue - 5 \\
\hline
\end{tabular}

\title{
The Law of Conversion Under Muslim Law Position of a Child and his Rights after Becoming a Major
}

\author{
Ankit Tiwari \\ B.B.A., LL.B (Hons), Indore Institute of Law \\ Indore, Madhya Pradesh, India
}

\section{INTRODUCTION}

On conversion to Islam, converts, no matter what their previous religion may have been, must be taken, at that moment, to have renounced their former religion and personal law, and to have substituted, in its place, the Muslim religion and so much of the personal law as necessarily flows from that religion. (AdvocateGeneral of Bombay v. Jimbabai, I.L.R. (1917) 41 Bom. 181)

Thus, an Indian Christian domiciled in India can, after his conversion to Islam, legally contract a second marriage with a Muslim woman while his former marriage with a Christian woman is still subsisting. (John Jiban Chandra Datta v. Abinash, I.L.R. (1932) 2 Cal. 12)

But, if the first marriage was contracted in England under English form, during its subsistence, the second marriage would be regarded as a nullity. (King v. Superintendent, Registrar of Marriages, Hammersmith, (1917) 1 K.B. 634) ${ }^{1}$

But the conversion of a Hindu wife to Islam does not ipso facto dissolve her marriage with her husband, and she would be guilty of bigamy if she marries again. (Mst. Nandi v. The Crown (1920) I.L.R. 1 Lah. 440)

In Khambatta v. Khambatta [(1934) 36 Bom. L.R.)], a Muslim married a Christian woman in the Christian form. The wife became a convert to Islam and the husband divorced her by talak. In these circumstances, the Court held that the divorce was valid.

\section{Problem:}

Yusuf, a Muslim, marries Rita, a Christian woman, in Scotland according to lex loci (i.e. the law of Scotland). They return to India where Rita embraces Islam. Can Yusuf divorce Rita by Talak?

$\mathrm{Y}$ Can divorce $\mathrm{R}$ by talak, $\mathrm{R}$ having embraced Islam.

The suceession of property of a convert to the Muslim religion would be governed by Muslim law, and not by the Indian Succession Act. The property, therefore, of a Hindu convert to Islam will devolve according to Muslim law.

But, in all such cases, the conversion must be bona fide, and not a colorable one, i.e., not a conversion with the sole purpose of evading the personal law to which such person is subject.

A Christian, married to a Christian wife, was cohabiting with another native Christian woman. Desirous of marrying the second woman, and in order to escape the punishment for bigamy, both the man and the native Christian woman declared themselves Muslims and went through a form of marriage according to Muslim law. It was held the marriage was not valid. (Skinners/. Orde, 14, M.I.A. 309

\footnotetext{
${ }^{1}$ ( https://www.lexology.com/library/detail.aspx?g=0b7ad5fc61bc-49f7-a382-ee6e2588f6d5 )
} 
Position of a child and his right after becoming major - Child custody is a term used in family law courts to define legal guardianship of a child under the age of 18. During divorce or marriage annulment proceedings, the issue of child custody often becomes a matter for the court to determine. In most cases, both parents continue to share legal child custody but one parent gains physical child custody. Family law courts generally base decisions on the best interests of the child or children, not always on the best arguments of each parent.

In general, courts tend to award PHYSICAL child custody to the parent who demonstrates the most financial security, adequate parenting skills and the least disruption for the child. Both parents continue to share legal child custody until the minor has reached the age of 18 or becomes legally emancipated. Legal custody means that either parent can make decisions which affect the welfare of the child, such as medical treatments, religious practices and insurance claims. Physical child custody means that one parent is held primarily responsible for the child's housing, educational needs and food. In most cases, the noncustodial parent still has visitation rights. Many of the religions practicing in India have their own personal laws and they have their different notion of custody.'

\section{Custody Under Hindu Law:}

All the personal law matrimonial statutes make provisions for dealing with the issue of child custody. The provisions in the matrimonial Acts can, however, be invoked only when there are some proceedings pending under the Act. Hindus have an additional Act, viz the Hindu Minority and Guardianship Act 1956 (HMGA). Apart from this, there is the Guardians and Wards Act 1890 (GWA). This is a secular law for appointment and declaration of guardians and allied matters, irrespective of caste, community or religion, though in certain matters, the court will give consideration to the personal law of the parties. The provisions of the HMGA (and other personal laws) and the GWA are complementary and not in derogation to each other, and the courts are obliged to read them together in a harmonious way. In determining the question of custody and guardianship, the paramount consideration is the welfare of the minor. The word 'welfare' has to be taken in its widest sense, and must include the child's, moral as well as physical well-being, and also have regard to the ties of affection."
The English and Indian decisions are replete with such statements that : (i) the children of tender years should be committed to the custody of the mother, (ii) older boys should be in the custody of the father, and (iii) older girls in the custody of the mother. But these are judicial statements of general nature and there is no hard. and fast rule. As to the children of tender years it is now a firmly established practice that mother. should have their custody since father cannot provide that maternal affection which are essential for their proper growth. It is also now ac for proper psychological development of children of tender years ma is indispensable.'

The Hindu Minority and Guardianship Act, 1956 contains a provision which lays down that custody of a child upon the age of five should ordinarily be with the mother. Under other personal laws, though it is no such statutory provision, the Indian courts have consistently taken view. The following observation of Beaumont, CJ. represents the judicial knew ......if mother is a suitable person to take charge of the child quite impossible to find an adequate substitute for her for the child.'

\section{In Re Kamal Rudra Das J. expressed the same view vividly thus:}

I have no doubt in my mind that the mother's lap is God's own cradle for a child of this age, and that as between father and mother, other things being equal, a child of such tender age should remain with mother."

But a mother who neglects the infant child as she does not want to sacrifice the type of life she leading can be deprived of custody. In respect of older children our courts take the view that the male children above the age of sixteen years and female children above the age of fourteen years, should not ordinarily be compelled to live in the custody to which they object.' However, even the wishes of the mature children will be given consideration only if they are consistent with their welfare! In 'Venkataramma v.. Tulsi',' the court disregarded the wishes of the children as it found these to induced by wholesale persuasion and were even tortured.'

Custody to third persons. -Ordinarily, custody should be given to either of the parents. But where welfare so requires, custody may be given to a third person. In 'Baby v., Vijay' granting custody of two minor 
children to maternal grandfather, the court observed that even if the father was not found unfit, custody might be given to a third person in the welfare of the child.'

\section{Custody Under Muslim Law:}

The first and foremost right to have the custody of children belongs to the mother and she cannot be deprived of her right so long as she is not found guilty of misconduct. Mother has the right of custody so long as she is not disqualified. This right is known as right of hizanat and it can be enforced against the father or any other person. The mother's right of hizanat was solely recognized in the interest of the children and in no sense it is an absolute right"

'Son-"Among the Hanafis, it is an established rule that mother's right of hizanat over her son terminates on the latter's completing the age of 7 years. The Shias hold the view that the mother is entitled to the custody of her son till he is weaned. Among the Malikis the mother's right of hizanat over her son continues till the child has attained the age of puberty. The rule among the Shafiis and the Hanabalis remains the same."

Daughter- Among the hanafis the mother is entitled to the custody of her daughters till the age of puberty and among the Malilikis, Shafiis and the Hanabalis the mother's right of custody over her daughters continues till they are married. Under the Ithna Ashari law the mother is entitled to the custody of her daughters till they attain the age of 7 . The mother has the right of custody of her children up to the ages specified in each school, irrespective of the fact whether the child is legitimate or illegitimate. Mother cannot surrender her right to any person including her husband, the father of the child. Under the Shia school after the mother hizanat belongs to the father. In the absence of both the parents or on their being disqualified the grandfather is entitled to custody. Among the Malikis following females are entitled to custody in the absence of mother:

1. maternal grandmother

2. maternal great grandmother

3. maternal aunt and great aunt

4. full sister

5. uterine sister

6. consanguine sister

7. paternal aunt
Father's right of hizanat- All the schools of Muslim law recognize father's right of hizanat under two conditions that are:

on the completion of the age by the child up to which mother or other females are entitled to custody.

In the absence of mother or other females who have the right to hizanat of minor children.

Father undoubtedly has the power of appointing a testamentary guardian and entrusting him with the custody of his children. Other male relations entitled to hizanat are:

1. nearest paternal grandfather

2. full brother

3. consanguine brother

4. full brother's son

5. consanguine brother's father

6. full brother of the father

7. consanguine brother of the father

8. father's full brother's son

9. father's consanguine brother's son

Among the Shias hizanat belongs to the grandfather in the absence of the father."

Applicability of the Shariat Law to proceeding for custody of the children under the Guardians \& Wards Act when the parties are governed by Muslim law, is the legal proposition that is dealt with by this article.

The Guardians and Wards Act, 1890, is the enactment that regulates and governs the law relating to appointment and declaration of guardians; duties, rights and liabilities of guardians and all laws relating to the Guardian and Ward. As per Section 4 of the Guardians and Wards Act, 1890 a minor is a person who, under the provisions of the Indian Majority Act is deemed not to have attained the age of majority. As it is well known that the age of majority for a person in India has been defined under Section 3 of the Indian Majority Act, 1875 stipulates "that every person domiciled in India shall be deemed to have attained his majority when he shall have completed his age of eighteen years and not before". Thus on the face of it an inference is drawn that all persons are considered minors if he or she has not attained the age of 18 years.

While India being a secular and democratic county, gives privileges and protection for various religions that flourish under the protection of the Constitution. 
People of different religions are governed by their respective Personal laws in all questions pertaining to succession, inheritance, marriage, divorce, etc. ${ }^{2}$

It is a false presumption that prevails that the Guardians and Wards Act, 1890 applies equally to all persons irrespective of their religion, customs and practices. It is pertinent to note that, the framers of the Guardianship Act were well aware of the diverse religious demography that exists in India. Keeping this in mind section 6 of the G\&W Act was enacted, which states that, "in case of a minor, nothing in this Act shall be construed to take away or derogate from any power to appoint a guardian of his person or property or both, which is valid by the law to which the minor is subject'".

The custody of a minor child in Islam is called Hizanit, which literally means the care of the infant. As per the Shariat law that applies to Muslims, the father is considered to be the natural guardian of his children irrespective of sex, but the mother is entitled to the custody of her son till the age of 7 years and of her daughter till she attains puberty. Thus under the Muslim law a male would attain majority/adulthood when he reaches the age of 7 years and a female would attain majority on attaining puberty.

The question that emerges is whether the Muslim personal law (Shariat) would also be applicable to a proceeding under the Guardianship Act. As stated earlier Section 6 gives scope for the application of the personal law to which the minor is subjected to. Further Section 17 of the G\&W Act also stipulates that a guardian has to be appointed in consonance with the personal law by which the parties are governed.

The said legal proposition was amply dealt with by the Hon'ble High Court of Delhi in Akhtar Begum vs Jamshed Munir, which held that "the personal law of the parties has to be kept in view in deciding an application for custody by virtue of the mandate of Section 6 of the Act. If a Court does not keep that in view it would be acting illegally and with material irregularity".

Further the Hon'ble High Court of Delhi while dealing with a habeas corpus petition in Mohammad
Nihal Vs State, has taken the aid of Section 2 of the Muslim Personal Law (Shariat) Application Act, 1937 which states that, regarding matters pertaining to succession, inheritance, marriage, divorce, guardianship, etc, where the parties are Muslims, the Muslim Personal Law (Shariat) shall be applicable. The Hon'ble Court has held that, "if some doubt prevails pertaining to the applicability of Shariat laws in guardianship matters, it stands clarified by virue of Section 6 of the $G \& W$ Act. When a court is called upon to determine the welfare of a minor so far as appointment of a guardian is concerned, this exercise will have to be determined in consonance with Shariat Law". The Hon'ble Court further reiterated that in consonance with section 2 of the Majortiy act which states that its provisions do not impact on matters of marriage, dower, divorce and adoption, the Indian Majority act cannot be looked into while ascertaining the age of a minor and the personal law of the parties would be the driving factor.

\section{CONCLUSION}

Although the personal law of the parties is to be taken into consideration while deciding the custody of the child, the welfare of the Child is of paramount importance and cannot be over-ruled by the personal law and the welfare of the child must be the deciding factor. However, at the same time the personal law cannot be completely sidelined as the personal law would be an important facet of the welfare of the child and must also be taken into consideration. A person is assumed to have the capacity to enter into a contract. An intoxicated person, minor, or mentally incapable person has two options available to them after entering into a contract which affects the validity of the contract into which they have entered. The first option they have is to disaffirm a contract. Disaffirming a contract reveals a desire by an individual to no longer be bound by the contract. The disaffirmation can be verbal or active.

\footnotetext{
2 ( http://www.childrensrights.ie/childrens-rightsireland/childrens-rights-ireland )
} 